\title{
Protein yield and mineral contents in Pereskia aculeata under high-density planting system ${ }^{1}$
}

\author{
Maria Regina de Miranda Souza 2 , Paulo Roberto Gomes Pereira ${ }^{3}$, \\ Rafael Gustavo Faria Pereira ${ }^{2}$, Ivan de Paiva Barbosa ${ }^{2}$, Maria Cristina Baracat-Pereira ${ }^{4}$
}

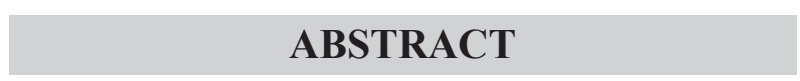

The development of technologies to increase the yield of Pereskia aculeata Mill. may contribute to its market insertion as an excellent source of protein. This study aimed to assess the influence of plant density on protein yield and mineral contents of $P$. aculeata leaves and branches. The experiment consisted of five treatments $\left(1\right.$ plant $\mathrm{m}^{-2}$, 5 plants $\mathrm{m}^{-2}, 10$ plants $\mathrm{m}^{-2}, 25$ plants $\mathrm{m}^{-2}$ and 50 plants $\mathrm{m}^{-2}$ ), in three blocks. Eight consecutive harvests were obtained over 12 months, and 10 plants $\mathrm{m}^{-2}$ was considered the best density, with yields of $144.0 \mathrm{t} \mathrm{ha}^{-1}$ year ${ }^{-1}, 25.6 \mathrm{t} \mathrm{ha}^{-1}$ year $^{-1}, 310.8 \mathrm{tha}^{-1}$ year $^{-1}$ and $58.3 \mathrm{tha}^{-1}$ year $^{-1}$, respectively for leaf fresh and dry matter, and branch fresh and dry matter. The average leaf protein content $(22.4 \%)$ was not influenced by plant density. The estimated total protein yields were $5,759 \mathrm{~kg} \mathrm{ha}^{-1}$ year $^{-1}$ and $9,035.3 \mathrm{~kg} \mathrm{ha}^{-1}$ year $^{-1}$, respectively in the leaves and branches with leaves. The high-density system with 10 plants $\mathrm{m}^{-2}$ in successive harvests is a fast way to produce large amounts of vegetable protein and mineral-rich leaves per area and time for human and animal feeding.

KEYWORDS: Pereskia aculeata Mill., non-conventional vegetables, vegetable protein, functional food.

\section{INTRODUCTION}

Farming leafy vegetables and adopting cultivation techniques that provide high yields of proteins, carbohydrates, vitamins, minerals and fibers per unit area and time, while using less water and energy, are vital to ensure food security for a sustainable human development.

\section{RESUMO}

Produtividade de proteína e teor de minerais em ora-pro-nobis sob sistema superadensado de plantio

O desenvolvimento de tecnologias para aumentar a produtividade de ora-pro-nobis poderá contribuir para a sua inserção no mercado como excelente fonte de proteína. Objetivou-se avaliar a influência do adensamento de plantas sobre a produtividade de proteína e teor de minerais em folhas e ramos de ora-pro-nobis. $\mathrm{O}$ experimento consistiu de cinco tratamentos (1 planta $\mathrm{m}^{-2}$, 5 plantas $\mathrm{m}^{-2}, 10$ plantas $\mathrm{m}^{-2}, 25$ plantas $\mathrm{m}^{-2}$ e 50 plantas $\mathrm{m}^{-2}$ ), em três blocos. Obtiveram-se oito colheitas consecutivas em 12 meses, e a densidade de 10 plantas $\mathrm{m}^{-2}$ foi considerada a melhor, com produtividades de matéria fresca e seca de folhas e de matéria fresca e seca de ramos com folhas de, respectivamente, 144 t ha $^{-1}$ ano $^{-1}$, 25,6 tha ${ }^{-1}$ ano $^{-1}, 310,8$ tha $^{-1}$ ano $^{-1}$ e 58,3 tha $^{-1}$ ano $^{-1}$. O teor médio de proteínas das folhas $(22,4 \%)$ não foi influenciado pelas densidades de plantio. Estimaram-se produções totais de proteína de $5.759 \mathrm{~kg} \mathrm{ha}^{-1} \mathrm{ano}^{-1}$ e $9.035,3 \mathrm{~kg} \mathrm{ha}^{-1}$ ano $^{-1}$ nas folhas e ramos com folhas, respectivamente. $\mathrm{O}$ sistema superadensado com 10 plantas $\mathrm{m}^{-2}$ em colheitas sucessivas é uma forma rápida de produzir grande quantidade de proteína vegetal e folhas ricas em minerais por área e tempo, para a alimentação humana e animal.

PALAVRAS-CHAVE: Pereskia aculeata Mill., hortaliças não convencionais, proteína vegetal, alimento funcional.

Pereskia aculeata Mill. (also known as Barbados gooseberry, blade-apple cactus, leaf cactus or rose cactus) is a perennial tropical species easy to grow and common in many domestic gardens, particularly in rural areas of Brazil. Its leaves are tender, moderately fleshy, and the youngest ones, in particular, are appreciated for their distinctive flavor, considered a delicacy in local cuisine (Kathounian

1. Received: Mar. 02, 2020. Accepted: Apr. 24, 2020. Published: June 10, 2020. DOI: 10.1590/1983-40632020v5062365.

2. Empresa de Pesquisa Agropecuária de Minas Gerais (Epamig Sudeste), Viçosa, MG, Brasil.

E-mail/ORCID: reginamiranda@epamig.br/0000-0002-6366-7422, rafaelgfp@gmail.com/0000-0002-5663-1106, ivan.barbosa@ufv.br/0000-0001-8266-4414.

3. Universidade Federal de Viçosa, Departamento de Agronomia, Viçosa, MG, Brasil. E-mail/ORCID: ppereira@ufv.br/0000-0002-2464-4471.

4. Universidade Federal de Viçosa, Departamento de Bioquímica e Biologia Molecular, Viçosa, MG, Brasil. E-mail/ORCID: baracat@ufv.br/0000-0002-7376-2837. 
et al. 1994). Its nutritional and productive values make the species an attractive source of nutrients and protein to alleviate food shortages, inclusion in food security programs (Souza et al. 2016b) and diversify family farming (Rocha et al. 2008, Souza et al. 2009, Madeira et al. 2016).

The primary requirements of a leafy vegetable for the commercial market are abundant leaf production and quality (Cavatte et al. 2011). $P$. aculeata is a climbing leafy cactus, whose leaves are rich in protein, calcium and iron (Almeida Filho \& Cambraia 1974, Takeiti et al. 2009, Almeida et al. 2014, Souza et al. 2016a), lysine (Almeida Filho \& Cambraia 1974) and mucilage (Duarte \& Hayashi 2005, Conceição 2013, Lima Junior et al. 2013). The plants also contain antioxidants, which delay aging in human cells and prevent cancer (Sartor et al. 2010, Almeida \& Corrêa 2012), dyslipidemia and diabetes, among others (Almeida 2012), characterizing the species as a functional food (Silva Júnior et al. 2010).

Iron is a particularly important mineral in $P$. aculeata, with concentrations ranging from $81 \mathrm{mg} \mathrm{kg}^{-1}$ to $207.8 \mathrm{mg} \mathrm{kg}^{-1}$ of dry weight (Oliveira et al. 2013, Souza 2013, Almeida et al. 2014). According to the World Health Organization, $20 \%$ to $30 \%$ of the global population is iron deficient (WHO 2002).

In addition to its consumption as a fresh leafy vegetable, $P$. aculeata is also dried and ground as a supplement, due to its high protein content (Fidélix et al. 2010). Rocha et al. (2008) analyzed the use of $2 \%$ dried $P$. aculeata in noodles and found that it increased their nutritional value, improving the diet quality.

In addition to human feeding, its leaves and branches may be used in animal feeding, either dried and ground or fresh, after passing through a chaff cutter.

Despite its high nutritional value, $P$. aculeata is only grown and used locally, what, in conjunction with the lack of suitable technology, makes creating a supply chain difficult. From a cultivation perspective, the plant is hardy and perennial, giving it an advantage over most other leafy greens. A fresh leaf production between 2,500 $\mathrm{kg} \mathrm{ha}^{-1}$ and 5,000 $\mathrm{kg} \mathrm{ha}^{-1}$ (Madeira et al. 2013) and $4.0 \mathrm{t} \mathrm{ha}^{-1}$ year ${ }^{-1}$ to $6.4 \mathrm{t} \mathrm{ha}^{-1}$ year $^{-1}$ (Madeira et al. 2016) have been reported.

There are few scientific studies on the agronomic aspects of Pereskia aculeata Mill.
(Tofanelli \& Resende 2011, Barbosa et al. 2012, Madeira et al. 2016) and those identified are largely in the fields of chemistry, pharmacology and botany (Almeida Filho \& Cambraia 1974, Duarte \& Hayashi 2005, Silva Júnior et al. 2010, Almeida et al. 2014).

The development of technologies aimed at increasing yield and commercial-scale cultivation could contribute to its inclusion in the market as an excellent source of abundant high-quality protein for human and animal feeding. In this respect, it is essential to determine the plant population that results in the largest leaf area index and, consequently, higher yields per unit area and time, while maintaining biological quality. Souza (2013) reported exceptionally high $P$. aculeata yields with successive crops and variable plant populations grown in greenhouse plots. As such, this study aimed to assess the effect of plant density on $P$. aculeata protein yield, as well as leaf and branch mineral content, under field conditions.

\section{MATERIAL AND METHODS}

The experiment was carried out at the Universidade Federal de Viçosa, Minas Gerais state,

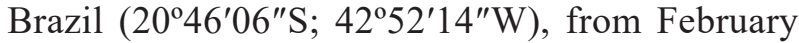
2011 to September 2012. Pereskia aculeata branches were collected and exsiccates were prepared and deposited in the herbarium of the Empresa de Pesquisa Agropecuária de Minas Gerais (number 57009), identified as Pereskia aculeata Miller (Souza 2013). Seedlings were produced using $0.8 \mathrm{~cm}$ wide and $20-25 \mathrm{~cm}$ long stakes from the middle portion of fully developed branches, and placed in $8 \mathrm{~cm} \mathrm{x}$ $15 \mathrm{~cm} \times 0.07 \mathrm{~cm}$ plastic bags for rooting and leaf emergence. The seedlings were transplanted at 45 days old to $1 \mathrm{~m}$ wide and $0.20 \mathrm{~m}$ long plots, with different plant densities.

A randomized block design was used, with 3 replications and 5 treatments, consisting of plant densities of 1 seedling $\mathrm{m}^{-2}, 5$ seedlings $\mathrm{m}^{-2}$, 10 seedlings $\mathrm{m}^{-2}, 25$ seedlings $\mathrm{m}^{-2}$ and 50 seedlings $\mathrm{m}^{-2}$, and a $15-\mathrm{cm}$ border along the length of the plots.

Thinning was performed when the stems exhibited fully expanded leaves, to ensure plot uniformity (Souza 2013), followed by the application of $200 \mathrm{~kg} \mathrm{ha}^{-1}$ of $\mathrm{N}$ as a urea solution in fertigation.

The first harvest was performed when the branches were fully developed, with completely expanded leaves on most of the branch. 
The middle section (largest part) of the branch was used for nutrient analysis, as described by Souza et al. (2016a). The material was ground and submitted to nitric-perchloric acid nitrogen digestion for quantification of $\mathrm{P}, \mathrm{K}, \mathrm{Ca}, \mathrm{Mg}, \mathrm{S}, \mathrm{Fe}$ and $\mathrm{Zn}$. Organic nitrogen was determined using the Nessler reagent after sulfuric acid digestion (Jackson 1958) and nitrate content $\left(\mathrm{N}^{-\mathrm{NO}_{3}}{ }^{-}\right)$via the method described by Cataldo et al. (1975). The protein content was estimated by multiplying the organic $\mathrm{N}$ content by a 6.25 factor (Gomes \& Oliveira 2011).

The average nutrient and protein contents were obtained in the first five crops. Nitrate contents for dry weight were converted into fresh weight $(1 / 100 \times \%$ DW) to enable comparison with international standards of the European Union (WHO 2002, Faquin 2004).

Statistical analyses were performed using the Genes software (Cruz 2013). Data were submitted to analysis of variance and fit to polynomial regression equations. The models were chosen based on the coefficient of determination, biological behavior and significance of regression coefficients, using the t-test at $5 \%$ of probability. For characteristics that could not be fit to a regression equation, the results were expressed based on means.

\section{RESULTS AND DISCUSSION}

Eight successive crops were obtained over 12 months. The increased plant density promoted a significant rise in the cumulative yield, as well as top, branch and leaf fresh and dry weight per unit area and time (Figures $1 \mathrm{~A}$ to $1 \mathrm{~F}$ ).

The maximum cumulative yield for top fresh weight was $387.1 \mathrm{t} \mathrm{ha}^{-1}$ year $^{-1}$, that is, $48.4 \mathrm{t} \mathrm{ha}^{-1}$ per crop every 1.5 months, with an estimated planted area of 34 plants $\mathrm{m}^{-2}$ (Figure 1A). Given that the number and cost of seedlings and labor are limiting factors in implementing agricultural crops, using fewer plants is a more viable alternative. For example, the 10 plants $\mathrm{m}^{-2}$ treatment produced an estimated $310.8 \mathrm{t} \mathrm{ha}^{-1}$ year $^{-1}$ of tops, only $20 \%$ less than the maximum yield obtained, which required 34 plants $\mathrm{m}^{-2}$ (Figure $\left.1 \mathrm{D}\right)$. The leaf fresh weight production using 10 plants $\mathrm{m}^{-2}$ was estimated at $144.1 \mathrm{t} \mathrm{ha}^{-1}$ year $^{-1}, 24 \%$ lower than the maximum yield of $189.2 \mathrm{t} \mathrm{ha}^{-1}$ year ${ }^{-1}$ obtained with 41.4 plants $\mathrm{m}^{-2}$ (Figure 1E). Additionally, as a perennial species, succession cropping allows plants to produce new branches until reaching the maximum leaf area index adjusted to light, temperature, water, nutrient and genotype conditions. As such, a density of 10 plants $\mathrm{m}^{-2}$ is suggested. The decision to use a larger number of seedlings to establish an agricultural crop depends on economic analysis based on the cost of seedlings and labor.

The fresh leaf production (Figure 1E) at a density of 10 plants $\mathrm{m}^{-2}$ and 8 successive crops was far higher than values reported in the literature of $2.5 \mathrm{t} \mathrm{ha}^{-1}$ year $^{-1}$ to $5.0 \mathrm{t} \mathrm{ha}^{-1}$ year- (Madeira et al. 2013). Souza et al. (2016a) assessed the $\mathrm{N}$ and protein content as a function of $\mathrm{N}$ doses using 1 plant per $1 \mathrm{~m}^{2}$ plot and three successive crops and obtained an average yield of $3.2 \mathrm{t} \mathrm{ha}^{-1}$ per crop. Crops grown in Brasília (Distrito Federal) and Palmeira (Paraná state) (Madeira et al. 2016), in two rows spaced $1.0 \mathrm{~m}$ apart, with $1.0 \mathrm{~m}$ to $1.25 \mathrm{~m}$ between plants, produced 5,714 plants $\mathrm{ha}^{-1}$. The authors estimated that, in field conditions, 4,000 plants with 6 to 8 successive crops a year would produce 4.0-6.4 $\mathrm{t} \mathrm{ha}^{-1}$ year $^{-1}$, considering that unused space was subtracted from the 1-hectare area. The same criterion was used in the plots in the present experimental study. Thus, the yield ha ${ }^{-1}$ year $^{-1}$ was calculated by multiplying the yield obtained with 10 plants in $1 \mathrm{~m}^{2}$ by $10,000 \mathrm{~m}$, over 8 successive crops, taking into account that spacing between plots will depend on the machinery used, its maneuvering area and crop management techniques, among others.

With regard to growing and harvesting this perennial species, another significant advantage of high-density planting in plots and regular harvesting is that it produces more compact plants in blocks whose width and length are influenced by the harvester to be used. This format allows the emergence of new branches without spines on the top and sides of the plant, facilitating harvesting and processing. As such, by mechanically harvesting and expanding the production scale of these plants with excellent biological quality, $P$. aculeata could contribute significantly to human food security and be used for feeding a variety of animals.

Leaf $\mathrm{N}, \mathrm{P}, \mathrm{Mg}, \mathrm{S}$ and $\mathrm{Zn}$ contents did not vary as a function of the different plant densities, with average values of $3.63 \mathrm{dag}^{-1} \mathrm{~g}^{-1}$, $0.56 \mathrm{dag} \mathrm{kg}^{-1}, 0.71 \mathrm{dag} \mathrm{kg}^{-1}, 0.24{\mathrm{dag} \mathrm{kg}^{-1} \text { and }}^{-1}$ $46.40 \mathrm{mg} \mathrm{kg}^{-1}$, respectively. However, leaf $\mathrm{Ca}, \mathrm{K}$ and Fe concentrations, as well as branch protein and $\mathrm{N}$ content, declined as plant density increased (Figures 2 and 3). This decrease in $\mathrm{Ca}$ and $\mathrm{K}$ cations and $\mathrm{Fe}$ may 
have been caused by self-shading, which contributed to reducing the transpiration and transport of these nutrients to the leaves. The manganese content increased with an estimated density of 35 plants $\mathrm{m}^{-2}$, declining again at greater densities.

Nutrient content is generally used to diagnose the nutritional status of plants, when compared to the critical level for the studied species. Although there are no references in the literature regarding critical levels for $P$. aculeata, the levels of all the nutrients analyzed here were higher than those suggested by Raij et al. (1996), Malavolta et al. (1997) and Marschner (1998) as an average leaf dry weight content for plants in general. Considering
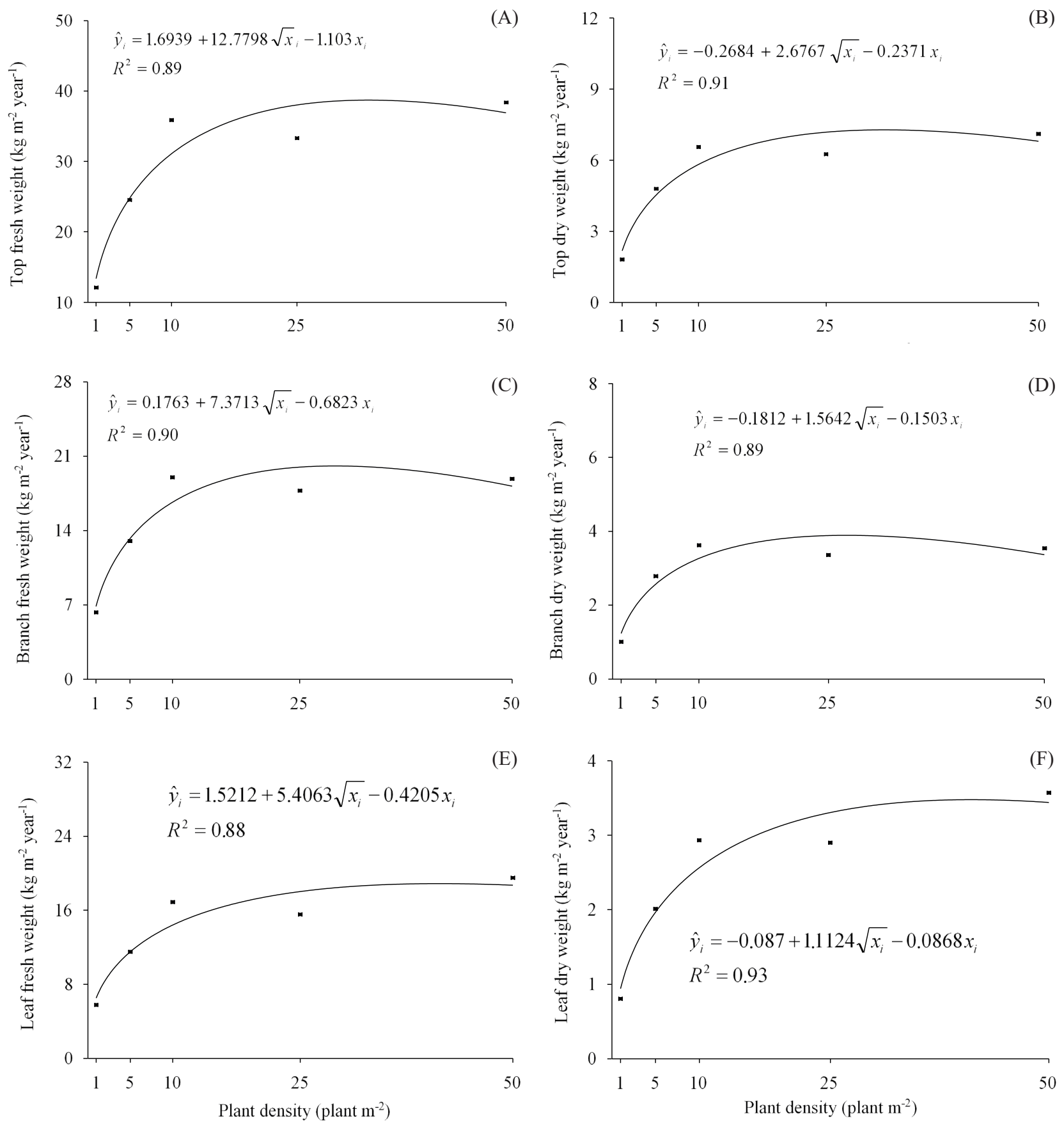

Figure 1. Top fresh (A) and dry (B) weight, branch fresh (C) and dry (D) weight, and leaf fresh (E) and dry (F) weight of Pereskia aculeata Mill., at different plant densities. 


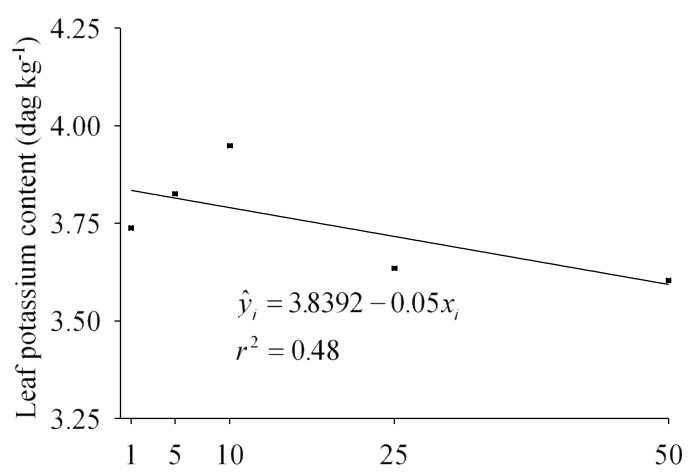

(A)
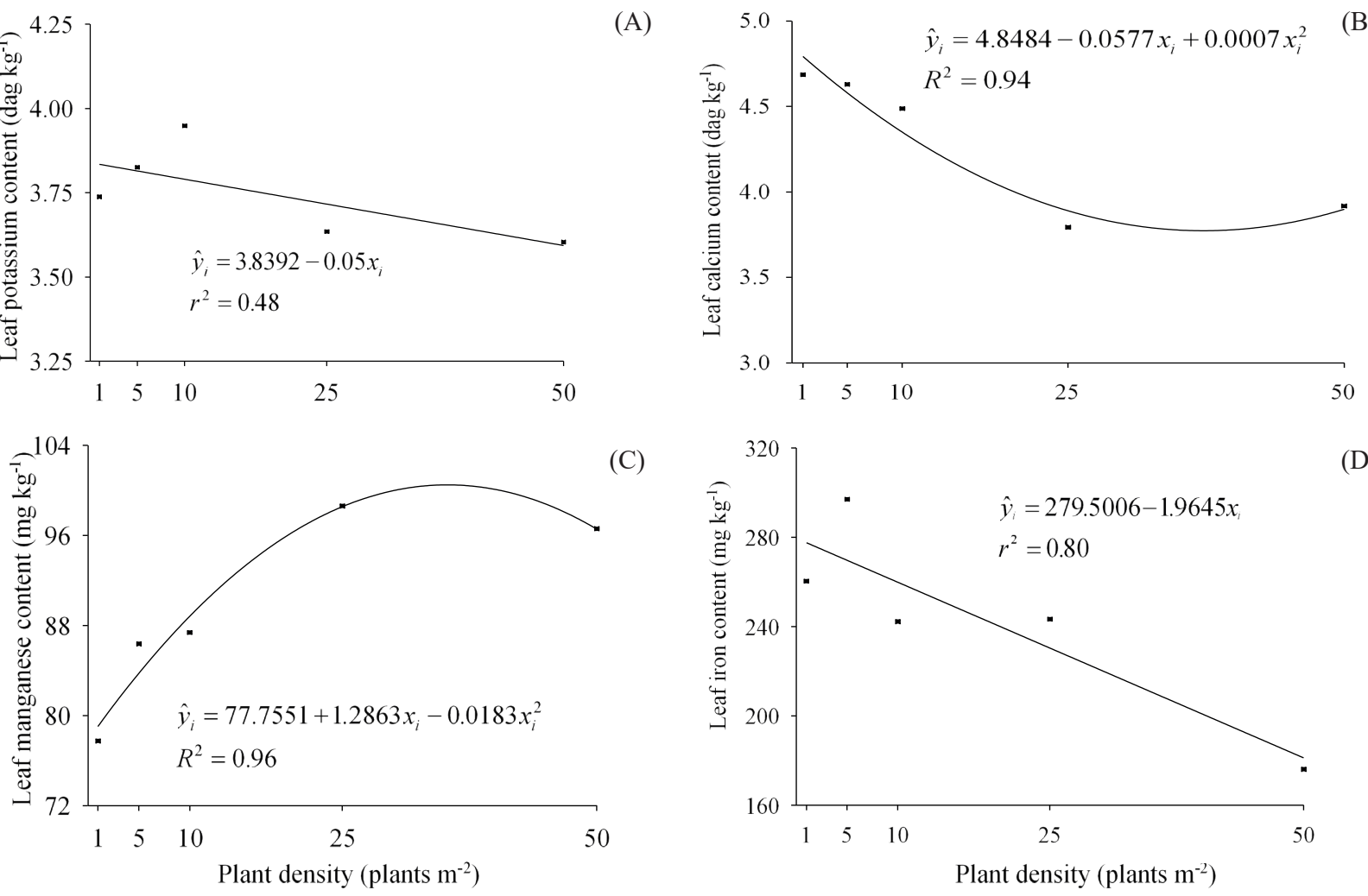

(C)

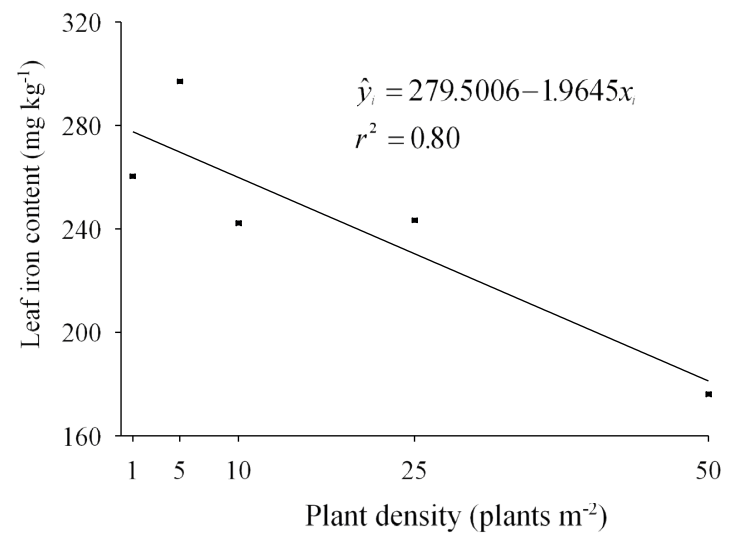

(D)

Figure 2. Leaf potassium (A), calcium (B), manganese (C) and iron (D) content of Pereskia aculeata Mill., at different plant densities.
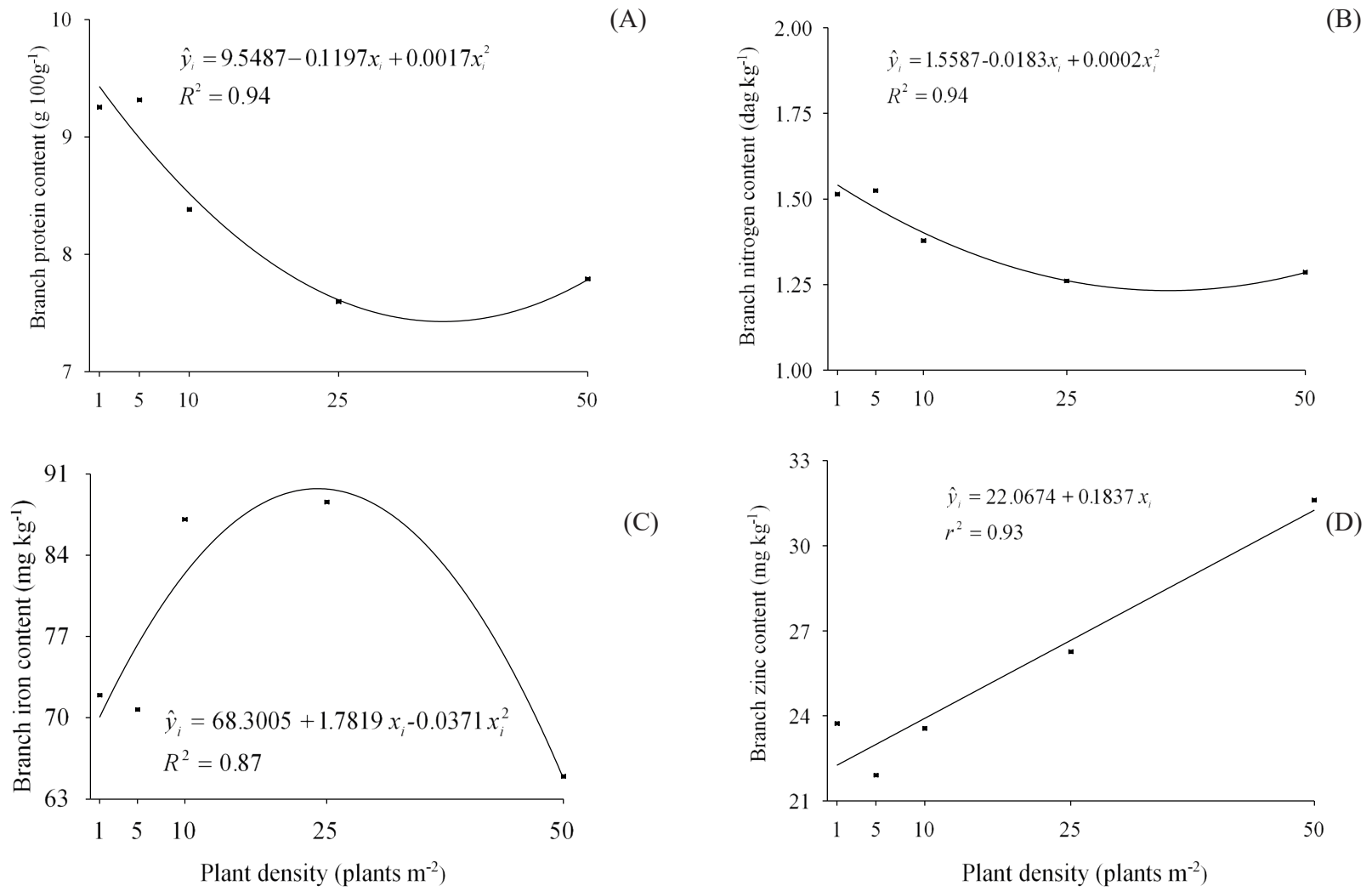

Figure 3. Branch protein (A), nitrogen (B), iron (C) and zinc (D) content of Pereskia aculeata Mill., at different plant densities. 
the high yields obtained here, the recorded nutrient concentrations could be used as a reference to diagnose the nutritional status of $P$. aculeata. Further research is needed to determine the critical levels for these plants.

Souza et al. (2016a) assessed the nutrient and protein content as a function of increasing $\mathrm{N}$ doses and at a dose of $200 \mathrm{~kg} \mathrm{ha}^{-1}$ of $\mathrm{N}$ for 1 plant $\mathrm{m}^{-2}$, and found average $\mathrm{N}, \mathrm{P}, \mathrm{Mg}, \mathrm{S}$ and $\mathrm{Zn}$ values of $3.52 \mathrm{dag} \mathrm{kg}^{-1}$, $0.47 \mathrm{dag} \mathrm{kg}^{-1}, 0.71 \mathrm{dag}_{\mathrm{kg}}^{-1}, 0.25 \mathrm{dag} \mathrm{kg}^{-1}$ and $36.64 \mathrm{mg} \mathrm{kg}^{-1}$, respectively, similarly to those recorded here.

The average leaf protein content was $22.42 \%$, similar to the value reported by Souza et al. (2016a). Based on this result and the leaf dry weight of $25.71 \mathrm{t} \mathrm{ha}^{-1}$ obtained with 10 plants $\mathrm{m}^{-2}$ (Figure $1 \mathrm{~F}$ ), the protein production was estimated at $5,759 \mathrm{~kg} \mathrm{ha}^{-1}$ year $^{-1}$. At this same plant density, considering an average branch protein content of $10.05 \%$ (Figure 3A), which represents $3,276.3 \mathrm{~kg} \mathrm{ha}^{-1}$ year $^{-1}$ of protein, the total protein production in the tops was estimated at 9,035.3 $\mathrm{kg} \mathrm{ha}^{-1}$ year $^{-1}$. This represents a nitrogen

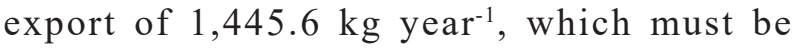
replenished via fertilization. Considering $70 \%$ of efficiency, a fertilization with $2,065.2 \mathrm{~kg}$ year ${ }^{-1}$ of $\mathrm{N}$ or $258 \mathrm{~kg}$ of $\mathrm{N}$ after each of the 8 harvests would be needed.

The protein production by $P$. aculeata was far greater than that reported for soybean and maize, the main protein sources for human and animal feeding.

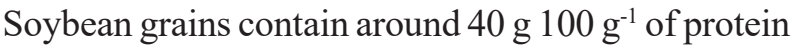
(Moraes et al. 2006), with a yield of 3,206 $\mathrm{kg} \mathrm{ha}^{-1}$ (Conab 2020). Considering $90 \%$ of grain dry weight (Cardoso 1996), the average protein production for the crop is estimated at $1,154 \mathrm{~kg} \mathrm{ha}^{-1}$ year-1. Regarding maize, based on an average yield of $5,719 \mathrm{~kg} \mathrm{ha}^{-1}$ (Conab 2020) and $90 \%$ grain dry

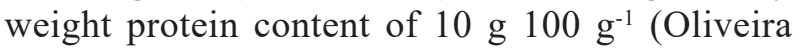
et al. 2004), the protein production is estimated at $514,7 \mathrm{~kg} \mathrm{ha}^{-1}$ year $^{-1}$.

A high-density cultivation of $P$. aculeata in succession cropping allows high yields of quality plant protein per unit area and time, with an easy harvest of branches from the top and sides of plants, which completely cover the plot. Additionally, high plant densities ensure a faster soil coverage, safeguarding against invasive plants and enabling a better use of solar radiation, water and nutrients (Zanine \& Santos 2004).

\section{CONCLUSIONS}

1. A high-density cultivation of Pereskia aculeata $\left(10\right.$ plants $\left.\mathrm{m}^{-2}\right)$, in a succession cropping system, allows the fast production of a large amount of high-quality plant protein and mineral-rich leaves per unit area and time, for human and animal feeding;

2. The leaf and top protein production by using 10 plants $\mathrm{m}^{-2}$ was estimated to be as high as $5,759 \mathrm{~kg} \mathrm{ha}^{-1}$ year ${ }^{-1}$ and 9,035.3 kg ha ${ }^{-1}$ year $^{-1}$, respectively, higher than the values obtained by crops considered important sources of protein for food.

\section{ACKNOWLEDGMENTS}

To the Fundação de Amparo à Pesquisa do Estado de Minas Gerais (Fapemig), for supporting this study; and to Cléverson Silva Ferreira Milagres, for contributing to the conduction of this research.

\section{REFERENCES}

ALMEIDA FILHO, J.; CAMBRAIA, J. Estudo do valor nutritivo do "ora-pro-nobis" (Pereskia aculeata Mill.). Revista Ceres, v. 21, n. 114, p. 105-111, 1974.

ALMEIDA, M. E. F.; CORRÊA, A. D. Utilização de cactáceas do gênero Pereskia na alimentação humana em um município de Minas Gerais. Ciência Rural, v. 42, n. 4, p. 751-756, 2012.

ALMEIDA, M. E. F.; JUNQUEIRA, A. M. B.; SIMÃO, A. A.; CORRÊA, A. D. Caracterização química das hortaliças não-convencionais conhecidas como ora-pronobis. Bioscience Journal, v. 30, n. 3, p. 431-439, 2014.

ALMEIDA, M. E. F. Farinha de folhas de cactáceas do gênero Pereskia: caracterização nutricional e efeito sobre ratos Wistar submetidos à dieta hipercalórica. 2012. Tese (Doutorado em Agroquímica) - Universidade Federal de Lavras, Lavras, 2012.

BARBOSA, C. K. R.; FINGER; F. L.; CASALI, V. W. D.; OLIVEIRA, L. S. de; PEREIRA, D. M. A. Manejo e conservação pós-colheita de Pereskia aculeata Mill. em temperatura ambiente. Horticultura Brasileira, v. 30, n. 2, p. 7002-7009, 2012.

CARDOSO, E. G. Engorda de bovinos em confinamento: aspectos gerais. Campo Grande: Embrapa Gado de Corte, 1996. (Documentos, 64).

CATALDO, D. A.; MAROON, M.; SCHRADER, L. E.; YOUNGS, V. L. Rapid colorimetric determination 
of nitrate in plant tissue by nitration of salicylic acid. Communications in Soil Plant Analysis, v. 6, n. 1, p. 7180, 1975.

CAVATTE, P. C.; MARTINS, S. C. V.; MORAIS, L. E.; SILVA, P. E. M.; SOUZA, L. T. A. Fisiologia dos estresses abióticos. In: FRITSCHE-NETO, R.; BORÉM, A. (ed.). Melhoramento de plantas para condições de estresses abióticos. Visconde do Rio Branco: Suprema, 2011. p. 39-79.

COMPANHIA NACIONAL DE ABASTECIMENTO (Conab). Acompanhamento da safra brasileira de grãos: safra 2019/20, $8^{\circ}$ levantamento. Brasília, DF: Conab, 2020.

CONCEIÇÃO, M. C. Otimização do processo de extração e caracterização da mucilagem de ora-pro-nobis (Pereskia aculeata Miller). 2013. Tese (Doutorado em Ciência dos Alimentos) - Universidade Federal de Lavras, Lavras, 2013.

CRUZ, C. D. GENES: a software package for analysis in experimental statistics and quantitative genetics. Acta Scientiarum, v. 35, n. 3, p. 271-276, 2013.

DUARTE, M. R.; HAYASHI, S. S. Estudo anatômico de folha e caule de Pereskia aculeata Mill. (Cactaceae). Revista Brasileira de Farmacognosia, v. 15, n. 2, p. 103 109, 2005.

FAQUIN, V. Acúmulo de nitrato em hortaliças e saúde humana. In: FAQUIN, V.; ANDRADE, A. T. Nutrição mineral e diagnose do estado nutricional de hortaliças. Lavras: UFLa/FAEPE, 2004. p. 46-51.

FIDÉLIX, M. P.; PULISTANO, V. M. S.; PEREIRA, C. A. M. Estudo experimental sobre as características nutricionais e sensoriais do ora-pro-nóbis (Pereskia aculeata Mill). Nutrição Brasil, v. 9, n. 6, p. 392-397, 2010.

GOMES, J. C.; OLIVEIRA, J. F. Análises fisico-químicas de alimentos. Viçosa: Ed. UFV, 2011.

JACKSON, M. L. Soil chemical analysis. New Jersey: Prentice Hall, 1958.

Khatounian, C. A. Produção de alimentos para consumo doméstico no Paraná: caracterização e culturas alternativas. Londrina: Iapar, 1994. (Circular, 81).

LIMA JUNIOR, F. A.; CONCEIÇÃO, M. C.; RESENDE, J. V.; JUNQUEIRA, L. A.; PEREIRA, C. G.; PRADO, M. E. T. Response surface methodology for optimization of the mucilage extraction process from Pereskia aculeata Miller. Food Hydrocolloids, v. 3, n. 1, p. 38-47, 2013.

MADEIRA, N. R.; AMARO, G. B.; MELO, R. A. de C. e; BOTREL, N.; ROCHINSK, E. Cultivo de ora-pro-nóbis (Pereskia) em plantio adensado sob manejo de colheitas sucessivas. Brasília, DF: Embrapa Hortaliças, 2016.
MADEIRA, N. R.; SILVA, P. C.; BOTREL, N.; MENDONCA, J. L. de; SILVEIRA, G. S. R.; PEDROSA, M. W. Manual de produção de hortaliças tradicionais. Brasília, DF: Embrapa, 2013.

MALAVOLTA, E.; VITTI, G. C.; OLIVEIRA, S. A. Avaliação do estado nutricional de plantas: princípios e aplicações. 2. ed. Piracicaba: Potafos, 1997.

MARSCHNER, H. Mineral nutrition of higher plant. 2. ed. New York: Academic Press, 1998.

MORAES, R. M. A.; JOSÉ, I. C.; RAMOS, F. G.; BARROS, E. G.; MOREIRA, M. A. Caracterização bioquímica de linhagens de soja com alto teor de proteína. Pesquisa Agropecuária Brasileira, v. 41, n. 5, p. 725-729, 2006.

OLIVEIRA, D. C. da S.; OLIVEIRA D. D. C. S.; WOBETO, C.; ZANUZO, M. R. E.; SEVERGNINI, C. Composição mineral e teor de ácido ascórbico nas folhas de quatro espécies olerícolas não-convencionais. Horticultura Brasileira, v. 31, n. 3, p. 472-475, 2013.

OLIVEIRA, J. P. D.; CHAVES, L. J.; DUARTE, J. B.; BRASIL, E. M.; FERREIRA JUNIOR, L. T.; RIBEIRO, K. D. O. Teor de proteína no grão em populações de milho de alta qualidade proteica e seus cruzamentos. Pesquisa Agropecuária Tropical, v. 34, n. 1, p. 45-51, 2004.

RAIJ, B. V.; CANTARELlA, H.; QUAGGIO, J. A.; FURLANI, A. M. C. (ed.). Recomendações de adubação e calagem para o Estado de São Paulo. 2. ed. Campinas: IAC, 1996. (Boletim técnico, 100).

ROCHA, D. R. de C.; PEREIRA JÚNIOR, G. A.; VIEIRA, G.; PANTOJA, L.; SANTOS, A. S.; PINTO, N. A. V. D. Macarrão adicionado de ora-pro-nobis (Pereskia aculeata Miller) desidratado. Alimentos e Nutrição, v. 19, n. 4, p. 459-465, 2008.

SARTOR, C. F. P.; AMARAL, V. do; GUIMARÃES, H. E. T.; BARROS, K. N. de; CORTEZ, L. E. R.; VELTRINI, V. C. Estudo da ação cicatrizante de folhas de Pereskia aculeata. Revista Saúde e Pesquisa, v. 3, n. 2, p. 149-154, 2010.

SILVA JÚNIOR, A. A.; NUNES, D. G.; BERTOLDI, F. C.; PALHANO, M. N.; KOMIEKIEWICZ, N. L. K. Pão de ora-pro-nobis: um novo conceito de alimentação funcional. Agropecuária Catarinense, v. 23, n. 1, p. 35-37, 2010.

SOUZA, M. R. M. Ora-pro-nobis (Pereskia aculeata Mill.) como alternativa promissora para produção de proteína: densidade de plantio e adubação nitrogenada. 2013. Tese (Doutorado em Fitotecnia) - Universidade Federal de Viçosa, Viçosa, 2013.

SOUZA, M. R. M.; CORREA, E. J. A.; GUIMARÃES, G. O potencial do ora-pro-nobis na diversificação da produção agrícola familiar. Revista Brasileira de Agroecologia, v. 4, n. 2, p. 3550-3554, 2009. 
SOUZA, M. R. M.; COSTA, C. A. C.; MILAGRES, C. S. F.; SALES, H. L.; CAIXETA, G. Z. T. Oportunidades de mercado para hortaliças não convencionais em Minas Gerais. Informe Agropecuário, v. 37, n. 295, p. 21-29, 2016 b.

SOUZA, M. R. M.; PEREIRA, P. R. G.; MAGALHÃES, I. P. B.; SEDIYAMA, M. A. N.; VIDIGAL, S. M.; MILAGRES, C. S. F.; BARACAT-PEREIRA, M. C. Teores de minerais, proteína e nitrato em folhas de orapro-nobis submetido a adubação nitrogenada. Pesquisa Agropecuária Tropical, v. 46, n. 1, p. 43-50, 2016 a.

TAKEITI, C. Y.; ANTÔNIO, G. C.; MOTA, E. M. P.; COLLARES QUEIROZ, F. P.; PARK, K. J. P. Z. Nutritive evaluation of a non-conventional leafy vegetable (Pereskia aculeata Miller). International Journal of Food Sciences and Nutrition, v. 60, n. 1, p. 148-160, 2009.

TOFANELLI, M. B. D.; REZENDE, S. G. Sistemas de condução na produção de folhas de ora-pro-nobis. Pesquisa Agropecuária Tropical, v. 41, n. 3, p. 466-469, 2011.

WORLD HEALTHORGANIZATION(WHO). Evaluation of certain food additives: fifty-ninth report of the joint FAO/WHO expert committee on food additives. Geneva: WHO, 2002.

ZANINE, A. M.; SANTOS, E. M. Competição entre espécies de plantas: uma revisão. Revista da Faculdade de Zootecnia, Veterinária e Agronomia, v. 11, n. 1, p. 1030, 2004. 